\title{
STATE TAXATION OF CORPORATE INCOME DERIVED FROM INTERSTATE COMMERCE: PUBLIC LAW 86-272 AND ITS ALTERNATIVES
}

Northwestern States Portland Cement Co. $v$. Minnesota ${ }^{1}$ estab-
lished $^{2}$ the constitutionality of state taxation of the income ${ }^{3}$ of
foreign corporations derived solely from interstate activities, ${ }^{4}$ pro-
vided that the tax is non-discriminatory and is properly apportioned

1358 U.S. 450 (1959).

2 Kust, State Taxation of Income From Interstate Commerce: New Dimensions of an Old Problem, 14 Sw. L.J. 1, 2 (1960).

s This comment attempts to clarify only the issues related to state income taxation, which is considered to be the heaviest burden on corporations. Three Tax Men Report on the State Tax Front Since Scripto and Northwestern, 14 J. TAxaTion 282, 285 (1961). See generally Developments in the Law-Federal Limitations on State Taxation of Interstate Business, 75 HARv. L. REv. 953 (1962).

In regard to sales taxes, in fiscal 1963 they accounted for one-fourth of all state revenues and were the prime source of revenue for thirty states. 24 CCH STATE TAX REv. No. 37 (Sept. 16, 1963). See generally Hearings on Sales and Use Taxes Before the Special Subcommittee on State Taxation of Interstate Commerce of the House Committee on the Judiciary, 87th Cong., 2d Sess. (1962); Kust \& Sale, State Taxation of Interstate Sales, 46 VA. L. REv. 1290 (1960).

- However, a tax on the privilege of doing business applied to foreign corporations is unconstitutional, even though the tax is apportioned on net income. Spector Motor Service, Inc. v. O'Connor, 340 U.S. 602 (1951). Of the Northwestern States decision it has been said: "No other case in recent years more clearly emphasizes the economically meaningless and purely mechanical nature of the tests employed by the Court to determine the validity of a tax under the commerce clause . ..." Hartman, State Taxation of Interstate Commerce: A Survey and An Appraisal, 46 VA. L. REv. 1051, 1099 (1960).

For examples and discussion of what was considered to be the right of states to tax interstate commerce before the Northwestern States decision, sce Independent Warehouses, Inc. v. Scheele, 331 U.S. 70 (1947); Minnesota v. Blasius, 290 U.S. I (1933); Hartman, supra at 1089-90; Wells, Federal Limitations on State Power of Taxation, 18 Bus. LAw. 563 (1963). But see West Publishing Co. v. McColgan, 27 Cal. 2d 705, 166 P.2d 861, aff'd per curiam, 328 U.S. 823 (1946).

The broader ramifications of Northwestern States seemed apparent to observers in the subsequent denial of certiorari in two cases where the corporate defendants had minimal contacts with the taxing state. Brown-Forman Distillers Corp. v. Collector, 234 La. 651, 101 So. 2d 70 (1958), appeal dismissed and cert. denied, 359 U.S. 28 (1959); International Shoe Co. v. Fontenot, 236 La. 279, 107 So. 2d 640 (1958), cert. denied, 359 U.S. 984 (1959).

'Income subject to multiple burdens is not taxable by the states, Michigan-Wis. consin Pipe Line Co. v. Calvert, 347 U.S. 157 (1954), but the burden of proving that a state's method of apportionment is unfair rests on the taxpayer. Commissioner v. Transcontinental Bus Sys., Inc., 227 Ark. 811, 301 S.W.2d 569 (1957). An apportionment formula need not be entirely accurate to be valid so long as it is generally equitable. Turco Paint \& Varnish Co. v. Kalodner, $320 \mathrm{~Pa}$. 421, 184 Atl. 37 (1936). For an example of an apportionment formula reaching an inequitable result, see Hans Rees' Sons v. North Carolina, 283 U.S. 123 (1931). Compare Butler Bros. v. McColgan, 
to local nexus-forming corporate functions. ${ }^{6}$ In order to shield small businesses from an anticipated increase in state taxation of interstate commerce and to provide certainty to the definition of nexus, ${ }^{7}$ Congress enacted Public Law 86-272 as a temporary measure. ${ }^{8}$ In essence, the statute exempts from state taxation income derived from "solicitation" alone within the taxing state." It was not intended to be an all-inclusive remedy but rather to serve until a more definitive solution could be devised after further congressional study of the numerous problems involved.

The purpose of this comment is to examine the impact of this statute on the limited problems which it was enacted to alleviate and to consider the more comprehensive alternative remedies in light of the effect of the statute on the administrative and economic problems of the area.

\section{Compliance Costs}

Aside from the tax itself, ${ }^{10}$ a major burden imposed on businesses engaged in interstate commerce when a foreign state taxes their

315 U.S. 501 (1942); El Dorado Oil Works v. McColgan, 34 Cal. 2d 73I, 215 P.2d 4, appeal dismissed, 340 U.S. 801 (1950).

During the 1960-1961 term, the Supreme Court refused to hear all six cases in which the taxpayer asserted that the apportionment formula was unfair. I P-H STATE \& Locat TAX SERv. If 91403 (1962).

a 358 U.S. at 452 . These requisites were met in the case although it is arguable that the resulting compliance burdens of state taxation could be an interference with interstate commerce thereby making the tax invalid under the doctrine of Freeman v. Hewit, 329 U.S. 249 (1946). See 358 U.S. at 476 (Frankfurter, J., dissenting opinion).

${ }^{7}$ See S. REP. No. 658, 86th Cong., Ist Sess. (1959); H.R. REP. No. 936, 86th Cong., Ist Sess. (1959).

8 73 Stat. 555 (1959), as amended, I5 U.S.C. $\$ \S 381-84$ (Supp. IV, 1963) [hereinafter cited as Public Law 86-272]. The constitutionality of this statute is presently being tested. International Shoe Co. v. Collector, 1 P-H Statr \& Local TAX SERv. If 9210I (La. Dist. Ct. July 12, 1963) (upheld). But see Roland, Public Law 86-272: Regulation or Raid, 46 VA. L. REv. 1172 (1960) (statute said to be unconstitutional).

- The statute relates only to the sale of tangible personal property and is applicable only if the orders are sent outside the state for acceptance or rejection and the goods are sbipped from outside the state. 73 Stat. 555 (1959), I5 U.S.C. § 381 (a) (1) (Supp. IV, 1963). If the sale is accomplished through the means of an independent contractor, as defined by 73 Stat. 555 (1959), I5 U.S.C. $\S 381$ (d) (I) (Supp. IV, 1963), who maintains an office within the state, the transaction is tax exempt under the provisions of 73 Stat. 555 (1959), 15 U.S.C. $\$ 381$ (c) (Supp. IV, I963).

${ }^{10}$ The tax is particularly burdensome when more than one state, or political subdivision thereof, taxes the same income. For example, the income from a sale may be taxed both in the state where the sale took place and in the state where the purchaser is located. See Hearings Before the Special Subcommittee on State Taxation of Interstate Commerce of The House Committee on the Judiciary, 87th Cong., 1st Sess., ser. 20, at 143-44 (1961) [liereinafter cited as Hearings].

The same result obtains when a corporation maintains within the foreign state a 
income is the compliance cost incidental to preparing the tax return. ${ }^{11}$ If the corporate activities within the taxing state yielded little income, the cost of preparing the return may exceed the tax itself. ${ }^{12}$ The compliance burden is particularly acute for businesses which derive a small amount of income from activities in each of a number of states, ${ }^{13}$ since the compliance cost is about the same regardless of the amount of tax paid. ${ }^{14}$

A primary cause of high compliance costs is the lack of uniformity among state requirements as to how a tax should be computed and what elements of business activity are allocable to the state for

branch affiliate which earns no profit during the tax year. The corporation may request that the state tax authorities permit the use of "separate" accounting to calculate the tax due. Where there is express statutory sanction for "separate accounting," it is within the tax administrator's discretion to allow its use. However, the taxpayer must show that unless separate accounting is used there will be substantial injustice. United States Rubber Prods., Inc. v. Tax Comm'n, 189 S.C. 386, 1 S.E.2d 153 (1939). Thirty states expressly provide for separate accounting. 1 P-H STATE \& LOCAL TAX SERV. I 1046 (1964). However, the state will not allow the use of "separate accounting" if it is determined that the operation of the branch was a part of a "unitary" corporate enterprise. As a result, the state will subject the corporation's activities to apportionment. However, it is rather unclear what elements of corporate organization make the enterprise "unitary." Compare Southern Pac. Co. v. McColgan, 68 Cal. App. 2d 48, 156 P.2d 81 (1945), with Cleveland-Cliffs Iron Co. v. Michigan Corp. \& Sec. Comm'n, 351 Mich. 652, 88 N.W.2d 564 (1958). See Palmolive Co. v. Conway, 56 F.2d 83 (7th Cir.), cert. denied, 287 U.S. 601 (1932); Buick Motor Co. v. City of Milwaukee, 48 F.2d 801 (7th Cir.), cert. denied, 284 U.S. 655 (1931); Hearings 43 (definition of separate accounting); $i d$. at 172 (separate accounting not accurate and rationale of "uni. tary'); id. at 179; Factors That Make a Business Unitary and Thus Subject to Apportionment, $11 \mathrm{~J}$. TAxaTion 240 (1959).

A Controllers Institute of America Survey, March 3, 1960, reprinted in Hearings at 496 , shows that $14.1 \%$ of responding firms reported that more than $100 \%$ of their income was subject to state taxation; but $43.6 \%$ of responding firms reported less than $100 \%$ taxation, the remaining firms not reporting on this issue.

11 While estimates vary, compliance cost of $\$ 250$ per return would appear to be average, although costs for some corporations have been much higher. Hearings 12122. See Hearings $273,330,449$ (various information required for tax return and the effect of uniformity). But see Hearings 87 (compliance cost estimates are unreliable); id. at 169 (compliance costs are not excessive in proper perspective).

Municipal taxation also creates complance problems. Hearings 138-39.

12 E.g., Hearings 121-22.

${ }^{13}$ A survey of 295 apparel firms reveals that 245 of the group sold their products in thirty or more states. The entire group earned a net profit, after federal taxes, of $1.4 \%$ which was an average of $\$ 30,000$ for 1960 . Hearings 224-25.

There are about 200,000 political subdivisions in the United States and in 1960 one small company filed 1000 tax returns representing an average tax liability of $\$ 241$. Id. at 392,395 .

Compliance costs and state taxation tend to force small to medium sized businesses to restrict themselves to regional activities and to induce the creation of subsidiaries, the result being less efficient business operations. Studenski, The Need for Federal Curbs on State Taxes on Interstate Commeree: An Economist's Viewpoint, 46 VA. L. REv. 1121, 1140 (1960).

16 Hearings 72, 442 . 
tax computation. ${ }^{15}$ As a result, even small corporations must maintain multifarious records, ${ }^{16}$ perhaps retain tax experts, ${ }^{17}$ and calculate the tax in compliance with various state requirements. ${ }^{18}$

In the majority of instances Public Law 86-272 has not functioned to reduce high compliance costs, even within its intended sphere of effectiveness. This is because a nexus statute does not alter the variation among states as to how a tax is calculated but rather only defines those occasions when a state may not impose the tax. The cost of compliance and the tax, of course, will be eliminated in those instances where the corporation's activities involve no more than "solicitation." If, however, the corporate operations exceed the boundaries marked by "solicitation," the statute provides no exemption from the imposition of a state tax, even if those corporate activities do not result in sufficient income to justify the cost of compliance. ${ }^{19}$

${ }^{15} \mathrm{It}$ is generally agreed that it is not the number of returns but rather the variation of the requirements of the returns, and the resulting record-keeping burden, which makes compliance costs excessive. E.g., Hearings 68, 78; Kust, supra note 2, at 9-10. See Cromwell, Auditor's Task Under New State Tax Rules is Difficult, but Much Help to Client, 13 J. Taxation 308 (1960); Three Tax Men Report on the State Tax Front Since Scripto and Northwestern, 14 J. TAxation 282, 284-85 (1961).

For example, under some circumstances a corporation when making a sales transaction may have to record the place where the order was accepted, the location of the negotiating personnel, the office where negotiated, the place of delivery, the origin of shipment, and perhaps other data in regard to the sale.

${ }^{10}$ See Cromwell, supra note 15; Three Tax Men Report on the State Tax Front Since Scripto and Northwestern, 14 J. TAXATION 282, 284-85 (1961). But see Hearings 169 (requirements of federal return supplies $90 \%$ of information required for state returns). Some large corporations have resorted to the use of electronic computers to keep the necessary records. For a discussion of their practical application and use, see Gildea \& Muhlberg, The Use of E.D.P. and Sampling Techniques in Compiling Data Required for State and Local Tax Returns, Hearings appendix VII. See also Symposium on Implications of Electronic Data Processing for Tax Administration and Tax Policy, 14 NaT'L TAx J. 209 (1961).

${ }^{17}$ Hearings 230 . See $i d$. at 121, where it is said that one firm with an annual sales volume of $\$ 45$ million is not sufficiently staffed to prepare state returns.

${ }^{18}$ See, e.g., Hearings 143-44. There is a great deal of variation among the states as to the tax treatment of dividends, stock rights, insurance proceeds, interest, royalties, annuities, business expenses, depletion, losses, bad debts, contributions, depreciation, and taxes (as a deductible item).

${ }^{10}$ For specific examples of the statute's failure see Hearings 118, 139-40. See generally Mickey \& Mickum, More Comprehensive Law Needed to Cure State Tax Muddle, 11 J. TAxamon 281 (1959); New Federal Limitation on State Taxes is Vague, Inequitable; Changes Foreseen, 11 J. TAXamon 279 (1959). But see Hearings 51, 107.

Public Law 86-272 and Northwestern States together give a tax advisor sufficiently clear indicia of what records must be kept. Graubart, Alert Tax Managers Shift Accounting Methods as Courts Change Rules, 13 J. TAxAтron 110 (1960). 


\section{State Administrative EXPENSE}

In the process of collecting and, if necessary, of investigating, discovering, and enforcing foreign corporate tax liabilities, the state incurs an administrative expense. ${ }^{20}$ Since the amount of tax revenue to be collected may not warrant the administrative expense which would be incurred, the state tax administrator may utilize his discretion in determining whether to assert a tax liability. ${ }^{21}$ This discretion has been criticized because it results in irregular enforcement of the tax laws, ${ }^{22}$ thereby depriving the corporations of certainty as to when a tax will be asserted. However, in attempting to provide that certainty, it would seem doubtful that any federal statute could force the administrator to assess a tax against all taxpayers liable. A uniform definition of nexus can encourage uniform

${ }^{20}$ No state administrative cost estimates are available, but Public Law 86.272 has increased costs and incidences of investigation. Hearings 211. Municipal tax administration costs constitute about $5 \%$ of the tax. Id. at 305 .

21 "State tax administrators are not interested in spending tax dollars to collect tax dimes." Cox, Federal Limit on State Taxes is Unfair to Consuming States and to Local Firms, 11 J. TAxation 354 (1959).

This discretion is also used to allow deviation from apportionment requirements when strict compliance would impose hardship on the corporation. However, in the absence of statutory permission, tax officials may not devise their own ailocation schemes. Commonwealth v. P. Lorillard Co., 129 Va. 74, 105 S.E. 683 (1921). But see District of Columbia v. Gallant Inc., 290 F.2d 745 (D.C. Cir. 1961); Revenue Conım'n v. Edgar Bros., 185 Ga. 216, 194 S.E. 505 (1937), appeal dismissed, 303 U.S. 626 (1938) (no final judgment). Such statutory grant is common. See, e.g., N. Y. TAX LAw \$ 210 (8). However, the taxpayer must first apply to the tax officials for relicf before the courts will grant relief. Turco Paint \& Varnish Co. v. Kalodner, 320 Pa. 421, 184 At1. 37 (1936).

While it is generally said that the deviation allowed must follow the statutory procedure, a state may be estopped to challenge the taxpayer's method of allocation under certain circumstances. See In re Kansas City Star Co., 346 Mo. 658, 142 S.W.2d I029 (1940) (continued acquiescence in taxpayer's method).

A state may also refuse to allow a foreign corporation to apportion its income, thereby subjecting all the corporation's income to taxation. People ex rel Tobacco \& Allied Stocks, Inc. v. Graves, 250 App. Div. 149, 294 N.Y. Supp. 995 (1997), aff'd, 277 N.Y. 723, 14 N.E.2d 821 (1938) (no dealings or assets outside taxing state). See Irvine Co. v. McColgan, 26 Cal. 2d 160, 157 P.2d 847 (1945); Montag Bros. v. State Rev. Comm'n, 50 Ga. App. 660, 179 S.E. 563 (1935); Cottonwood Coal Co. v. Junod, 73 Mont. 392, 236 Pac. 1080 (1925).

Tax officials are also generally given permission to promulgate regulations for accounting methods. But once the taxpayer has adopted a particular method of accounting, he must secure permission from the state tax officials to change this method. Commonwealth v. Electrolux Corp., 362 Pa. 333, 67 A.2d 105 (1949).

${ }^{22}$ Kust, supra note 2, at 13. See Hearings 6; Studenski, supra note 13, at 1134.37. But see Cox, supra note 21 , at 356.

The discretionary tax exemption gives untaxed corporations a competitive advantage, but those corporations are often new or small businesses which are not truly competitors of the taxed corporations. The effect is to subsidize smaller corporations earning little income within the state. 
enforcement of tax laws by exempting from taxation all those corporations whose tax would be an inadequate compensation for the state's outlay, even in the absence of a nexus statute's impediment. Those corporations still taxable ideally would be those which the administrator in his discretion would find profitable to tax.

However, Public Law 86-272 was enacted at the behest of the representatives of the business sector of the economy and was not designed to mitigate the problems befalling state tax administrators. $^{23}$ The statute deprives the administrator of his discretionary prerogative whenever the corporation in question does no more than solicit within the state. Nevertheless, the statute can function to exempt from taxation corporations earning within the state substantial income which would more than justify the administrative costs involved. ${ }^{24}$ Moreover, many corporations whose present methods of doing business are not exempt under the statute could modify those methods and thus secure exempt status. ${ }^{25}$

${ }^{23}$ Only two states were represented at the hearings prior to the enactment of Public Law 86-272. See Hearings Before the Select Committee on Small Business of the Senate Committee on Finance, 86th Cong., Ist Sess. (1959).

s Ten corporations doing business in California and claiming exemption under Public Law 86-272 have California sales ranging from $\$ 1,038,000$ to $\$ 3,658,000$. Hearings 167. See Cox, supra note 21, at 356-57. Further revenue losses accrue to the states when corporations claim to be exempt under Public Law 86-272 when in fact they are not exempt. Hearings 207-08. $\$ 4.5$ billion of a national total of $\$ 200$ billion of retail sales is conducted by house-to-house salesmen and catalog advertising. Bureau of Census, Retail Trade, Summary Statistics, 1 Census of Business, $1-7$ (1958). For the effect of the statute on the states, see Hearings 83, 87 (Georgia); id. at 90, 96, 98, 101, 382 (Michigan); Comment, 39 ORE. L. REv. 283, 292-95 (1960) (western states).

However, it is said that states realize little revenue from taxation of interstate commerce. Hearings 312 (less than $.3 \%$ of total revenues). Much of this can be traced to the apparent inefficiency of state revenue departments in enforcing their tax laws. Id. at 54. See id. at 401 .

Public Law 86-272 also allows taxation of corporations earning little income within the state. See Cox, supra note 21, at 356; Hearings 118, 139-40, 148; note 19 supra and accompanying text.

For discussions of the related issue of whether state taxation of interstate commerce and the resultant compliance costs place interstate business at an economic disadvantage with intrastate business, and the effect thereon of Public Law 86-272, see Hearings 90, 166, 233, 352; Barber, State Taxation of Net Income Derived from Interstate Commerce, 48 A.B.A.J. 1133, 1134 (1962); Cox, supra note 21; Kust, supra note 2, at 9-10; Studenski, supra note 13, at 1140-41.

as $\$ 25.3$ billion of $\$ 25.8$ billion wholesale sales and $\$ 130$ billion of $\$ 648$ billion of retail, wholesale and manufacturer's sales in 1958 already qualify or could be easily made to qualify for exempt status under Public Law 86-272. Hearings 360. Such changes would cost Pennsylvania $\$ 20$ million and Michigan $\$ 13.5$ million annually in tax revenues. Hearings 363, 382. Corporations, however, apparently have not changed their methods of doing business because of the presently temporary nature of Public Law 86-272. Hearings 364. See id. at 84. For the time being, "the situation is presently administered with a kind of rough justice, since the cost of compliance 


\section{Voluntary Tax Compliance}

In a system of voluntary self-assessment of taxes, the question whether a tax is due should be shrouded with as little uncertainty as possible. It is essential that the corporation know what activities within the foreign state will create an adequate nexus on which that state may predicate an assertion of tax liability. ${ }^{26}$ Therefore, what constitutes a tax nexus should be, insofar as possible, certain and predictable. $^{27}$

Public Law 86-272, attempting to define what is not a tax nexus, adds little certainty to the question. Whether the doing of certain activities goes beyond "solicitation" under the statute is subject to diverse interpretation, ${ }^{28}$ conceivably resolvable only by judicial

to those active out-of-state enterprises which presently bear the burden of the tax is comparatively less than the cost which would be incurred by the small businessman if the laws were uniformly enforced." Wells, supra note 4, at 568. Thercforc, it would seem that if many corporations were to change their methods of business to gain exemption under Public Law 86-272, a heavier tax and compliance burden would fall upon intrastate business and interstate businesses unable to adjust their modes of operation. Presumably, these corporations would be comprised for the most part of small businessmen.

${ }^{26}$ The compliance costs to be incurred are also an important consideration in determining whether to do business in a state. Hearings 59, 129, 390.

${ }^{27}$ See Hearings $74,128,131,135,238$. In determining whether to pay a tax, mucb consideration is given to the question of how strictly a state enforces its tax laws. Hearings 218. Therefore, the states have resorted to new methods of locating the taxpayer. For example, Illinois has opened a permanent office in New York City. States Increasingly Reach Outside Borders for Taxes, 17 J. TAxation 247 (1962). Other methods include study of telephone directories, motor vehicle registrations, advertising, and sales tax returns.

Even if the state discovers the taxpayer, there remains the problem of judicial enforcement. Many states have enacted long reaching scrvice of process statutes. Sce, e.g., CAL. CoRP. CODE $\S \S 6501,6502,6504$; KAN. GEN. STAT. ANN. 17.509 (1950); KY. REv. Stat. § 271.610 (1960); LA. REv. Stat. § 13.3471 (5) (1950); N.C. GeN. Stat. \$ 1-98 (1953). If the state can obtain jurisdiction over the corporation, foreign states will enforce the judgment. Milwaukee County v. M. E. White Co., 296 U.S. 268 (1935). However, if jurisdiction cannot be obtained, generally at common law a foreign state will not entertain an original action. Therefore, states have enacted rcciprocity statutes agreeing to entertain such actions. Twenty-eight states have cnacted such statutes. See 1 CCH Corp. LAw Guide If 2021, at 4026. See, e.g., LA. REv. STAT. § 47.3 (Supp. 1960). See also State v. Neely, 225 Ark. 230, 282 S.W.2d 150 (1955); City of Detroit v. Gould, 12 Ill. 2d 297, 146 N.E.2d 61 (1957); Ohio Dep't of Taxation v. Kleitch Bros., 357 Mich. 504, 98 N.W.2d 636 (1959), 13 J. TAxation 215 (1960).

On state tax administration generally, see Penniman \& Heller, State Income TaX Administration (1959).

${ }^{28}$ Hearings 49, 136, 237, 292-94. See also Hearings 109 (attempted definitions of "solicitation"); id. at 74 (four reasons a corporation may not pay a tax); 1 P-H CoRP. SERV. II 7299-301, and cases cited therein (what constitutes "solicitation" at common law and when it becomes "doing business"); 1 P-H STATE \& LOCAL TAX SERv. I 91175-R at 91237-39 (when particular states intend to impose a tax, since 1959, in cortain enumerated circumstances). 
determination. ${ }^{29}$ There is likely to be a divergence of opinion between state and the taxpayer since the states have indicated a predilection in favor of a constrictive interpretation of the statute ${ }^{30}$ while corporations have shown a contrary partiality. ${ }^{31}$ Furthermore, if the corporation should turn to the common law for a definition of what constitutes a tax nexus, an equally cryptic definition is afforded, ${ }^{32}$ and one likewise subject to its interpreter's predisposition. Recourse to judicial machinery to determine the nexus issue, either under Public Law 86-272 or at common law, involves an expense and inconvenience which the corporate taxpayer is unlikely to be willing to incur if the amount of the tax is small, thus permitting the state to prevail on default of judicial contest. As a product of the presently opaque status of "nexus," corporations are left without a definite guide for decision and must often rely on conjecture, a procedure fraught with the danger of back taxes and penalties. $^{33}$

\section{Proposed Comprehensive Nexuses}

While Public Law 86-272 has not functioned to alleviate the problems faced by the states and most corporations, it has served to delineate the difficulties with which a more comprehensive nexus solution must cope. In evolving a permanent solution, particular

\footnotetext{
${ }^{20}$ However, no cases have yet been reported involving the meaning of "solicitation" in Public Law 86-272.

so Hearings 73, 136.

${ }^{31}$ See Hearings 211-12.

32 "Whether due process is satisfied must depend rather upon the quality and nature of the activity in relation to the fair and orderly administration of the laws ...." International Shoe Co. v. Washington, 326 U.S. 310, 319 (1945). See Hearings 131. State statutory definitions generally offer no help. "Every [foreign or domestic] corporation shall be deemed to be doing business within this State if it engages within this State in any activities or transactions for the purpose of financial profit or gain, whether or not such corporation qualifies to do business in this State, and whether or not it maintains an office or place of doing business within this State, and whether or not any such activity or transaction is connected with interstate or foreign commerce." Ga. Code ANN. § 92-3113 (1961) (emphasis added.) See LA. Rev. STAT. § 47.31 (4) (1950); MinN. STAT. ANN. \$290.03 (1962); N.C. GEN. STAT. § 105-131 (3) (1958).

${ }^{33}$ Hearings 108. For an assertion that state tax officials intentionally refrain from asserting a tax hability until the total tax due, plus interest and penalties, is sufficient to justify the expense of collecting the tax, see Fearings 288 . The neglect or unauthorized action of state officials does not estop the state from asserting tax liabilities. Colver v. Miller, 127 Kan. 72, 272 Pac. 106 (1928).

Because there is often no statute of limitations applicable to taxes, see Wasteney v. Schott, 58 Ohio St. 410, 51 N.E. 34 (1898), state tax officials, as a result of the Northwestern States decision, intend to assert back taxes for prior years. See 1 P-H STATE \& LOCAL TAX SERv. I 91175-R, at 91234 (list of states and years for which liability will be enforced). Public Law 86-272 restricts imposition of a tax on corporations
} 
attention should focus on the need for a clear definition of nexus and the importance of a fuller comprehension of the states' problems. The basic difference among the proposed alternative nexus solutions is the degree to which each pre-empts state administrative discretion.

One alternative would be to repeal Public Law 86-272 and enact no other nexus statute, thereby entrusting to the plenary discretion of the state the decision whether to tax, subject only to constitutional limitations on what constitutes a tax nexus. ${ }^{34}$ This approach is premised on the likelihood that the instances in which the administrator decides not to assess the tax because of administrative expense or inconvenience would closely parallel those occasions in which the imposition of the tax would result in an onerous compliance problem for the corporation. ${ }^{35}$ However, this suggestion would merely restore the situation prior to Public Law 86-272 and would not alleviate any of the problems arising from state taxation of corporate income from interstate activities.

As an amendment to Public Law 86-272, or concomitant with its repeal, it has been suggested that minimum nexus should be defined in terms of doing a specific dollar amount of business within a state during the tax year. ${ }^{36}$ This proposal is posited on the view that, since burdensome compliance costs and the tax administrator's discretion are both functions of the amount of income earned from within the state, ${ }^{37}$ a quantitative rather than qualitative definition

exempt under the statute's provisions for years prior to September 14, 1959, unless such tax was imposed or assessed prior thereto. 73 Stat. 556 (1959), 15 U.S.C. $\$ 382$ (Supp. IV, 1963). Furthermore, some state courts, by analogy, impose a statute of limitations on tax claims. San Diego v. Higgins, 115 Cal. 170, 46 Pac. 923 (1896) (analogy to statute of limitations for liabilities based on statute).

34 Cox, supra note 21, at 354. See Hearings $142,145,170$.

${ }^{35}$ See Cox, supra note 21 , at 354 .

${ }^{36}$ The amount usually suggested is $\$ 100,000$. See Hearings 380 . This comment considers the proposal's effect only when enacted concomitant with the repeal of Public Law 86-272. During the Senate debate in regard to Public Law 86-272's enactment, Senator Long proposed a $\$ 250,000$ nexus definition combined with an excmp. tion for business done in any state with a population less than onc-half million. In this form, the proposal met with constitutional objections. Senator Long withdrew the population exemption, but the proposal was still rejected by voice vote after debate. See 105 Cong. REc. 16495 (1959) (proposal of Senator Long); id. at 16498 (objections of Senator Ervin); id. (objections of Senator Kerr); id. at 16499 (objections of Senator Lausche); id. (objections of Senator Ervin after population exemption removed).

37 "Assuming that it costs $\$ 200$ for a business to prepare a state tax return, it would seem safe to say that in the case of firms doing less than $\$ 100,000$ of business in any state, costs of compliance to the taxpayer and costs of administration and enforcement by the state will exceed any given revenuc." Dane, Small Business Lools 
of nexus is most realistic. ${ }^{38}$ However, the proposal is objectionable to the extent that a corporation would have to maintain the same records to prove its exemption from taxation that it would have to maintain were it subject to taxation. ${ }^{39}$ Furthermore, the dollar amount of business done within the state sometimes has no close relation to net income. ${ }^{40}$

Finally, it has been proposed that nexus should be defined in terms of maintaining a statutorily defined permanent establishment ${ }^{41}$ within the foreign jurisdiction. ${ }^{42}$ The adoption of this proposal would provide certainty of nexus and engender uniform enforcement of the tax laws since a state can easily locate a permanent establishment. ${ }^{43}$ Moreover, the employees of a permanent establishment would presumably be familiar with local tax requisites and procedures. ${ }^{44}$ The flaw in this proposal is that it would allow corpora-

at Public Law 86-272 in The Perspective of Its Alternatives, 46 VA. L. REv. 1190, 1202 (1960) (the author's conclusion, however, does not support the dollar nexus). See Hearings 124.

${ }^{38} \mathrm{~A}$ "quantitative" definition would be one such as a dollar amount of sales within the state while a "qualitative" definition would be one such as a "permanent establishment" or "solicitation."

That the courts, in determining whether a tax nexus exists at common law, in fact do employ a quantitative test, see Hearings 130-31. However, the language of the courts does not sustain the proposition. "The test is not merely, as has sometimes been suggested, whether the activity . . i is a little more or a little less." International Shoe Co. v. Washington, 326 U.S. 310,319 (1945).

BD Hearings 75.

10 Hearings 282. For other criticisms see Hearings 74-75, 110, 156. In particular, it is said that the use of subsidiaries would permit tax avoidance under a dollar amount nexus. Hearings 225-26. However, the courts have not been hesitant to disregard the separate entity of the subsidiary and to require consolidation of the overall corporate enterprise for taxation purposes, if necessary to prevent tax avoidance or evasion. See, e.g., Edison California Stores, Inc. v. McColgan, 30 Cal. 2d 472, 183 P.2d 16 (1947); In re Morton Salt Co., $150 \mathrm{Kan} .650$, 95 P.2d 335 (1939); Beneficial Loan Soc'y v. State Tax Comm'n, 163 Ore. 211, 95 P.2d 429 (1939).

"A "branch, management, factory, or other fixed place of business," not including an agency "unless the agency has, and habitually exercises, a general authority to negotiate and conclude contracts ... or has a stock of merchandise from which he regularly fills orders." Hearings 6 . See the proposed definition of "doing business" of the Committee on State and Local Taxation, Controllers Institute of America, April 14, 1961, amended Nov. 15, 1961.

4 This solution is supported by most businessmen and authorities. E.g., Barnes, Prerequisites of a Federal Statute Regulating State Taxation of Interstate Commerce, 46 VA. L. REv. 1269, 1280 (1960); Dane, supra note 37, at 1209; Kust, supra note 2, at 14.

However, uniform enforcement would not necessarily result, because the state tax official would not enforce the tax laws against corporations who failed to earn sufficient income within the state to justify the administrative expense. See text accompanying note 21 supra.

${ }^{18} \mathrm{Kust}$, supra note 2, at 14. Maryland favors this approach in light of its enforcement problems. Hearings 178-79.

" Barnes, supra note 42 , at 1280. 
tions doing substantial business within the state to avoid taxation by the expendiency of not maintaining a permanent establishment within the state. ${ }^{45}$

\section{UNIFORM APPORTIONMENT AND INCOME BASE}

A nexus statute, in defining when a state may not impose a tax, is not designed to mitigate the diversity of state income base definitions and apportionment requirements. ${ }^{46}$ Yet, it is this diversity which produces high compliance costs. If a tax can be and is imposed, the rigors of compliance are not allayed. Therefore, to alleviate the compliance burden, the adoption ${ }^{47}$ of uniform apportionment and definition of income base formulas has been suggested as a remedy which would abrogate the present diversity of state requirements. Thus, while a nexus statute reduces the number of returns which must be filed, thereby obviating the nusiance return in situations where corporate connections with the state are minimal, uniform definition and apportionment of income provisions abate much of the expense of compliance with taxes not exempt under the provisions of a nexus statute. ${ }^{48}$

${ }^{45}$ Hearings 153-54, 343. That the adoption of the permanent establishment nexus would not seriously affect state revenues, see Hearings 312.

It has been said that the reallocation of income to another state, when no permanent establishment is maintained within the state allowed to tax the transaction, would prevent tax avoidance under the permanent establishment nexus. Hearings 152. However, the proposed uniform apportionment formula which provides for reallocation is said to reallocate only in those instances when the corporation is subject to $\mathrm{a} \operatorname{tax}$ in the foreign jurisdiction and the state does not tax. Therefore, if the corporation maintained no permanent establishment within that state, it would not be subject to a tax and thereby avoid reallocation. 1 P-H STATE \& LOCAL TAX SERv. 91409 , at 91374 (intent of framers of uniform apportionment formula proposed by National Conference of Commissioners on Uniform State Laws). For conflicting views on reallocation, see authorities cited note 55 infra.

${ }^{40}$ For example, there is the following diversity among state requirements for receipt allocation: Location of place of delivery-23 states, location of office where negotiated-17 states, location of property at time of order -8 states, location of receipt or acceptance of order-12 states, location of negotiating personnel-6 states, location of shipment origin-15 states, other-19 states. 1 P-H STATE \& LOCAL TAX SERv. Report Bulletin No. 31, superseding f 1047 (Feb. 18, 1964). For diversity of state requirements as to income base, sce note 18 supra.

${ }^{47}$ Since the states have failed to act in the area, a uniform federal act will be required. See, e.g., Hearings 75, 92, 121.

That Congress has the power to act, see REPORT of TASK Force ON CONSTITUTIONality, Subcommittee on Congressional Enactment, A.B.A. Committee on State and LOCAL TAXES (1960); Kust, supra note 2, at 21-22. But see Roland, supra note 8.

${ }^{48}$ It would seem clear that a uniform formula would contribute much to the facilitation of voluntary tax compliance by clarifying requirements and their meaning. However, not everyone favors a uniform act. See Hearings 145 (fear of federal control); id. at 248 (would not help small businesses); id. at 271. 
The most predominant appointment formula is the "Massachusetts" or "three-factor" method by which the percentage of income taxable is determined by the proportion of the corporation's property, payroll, and sales within the taxing state. ${ }^{40}$ While the treatment of the property and payroll factors in a uniform apportionment formula is the subject of little debate, it is unsettled whether a sales factor should be included within a formula and, if it is, to what state the sale should be allocated.50

A corporation has little difficulty calculating the property and payroll factors in a tax return; the bulk of compliance expense is incurred with regard to the computation of the sales factor. ${ }^{51}$ This fact lends practical sustenance to the proposition that the sales factor should be excluded from a uniform formula. The theoretical basis for this view is that property and payroll alone produce the income which the state is endeavoring to tax; and, therefore, to permit inclusion of the sales factor within an apportionment formula is fallacious. ${ }^{52}$

This theoretical argument has been rejected as inapplicable in the field of taxation. ${ }^{53}$ Moreover, if the sales factor were excluded

${ }^{\circ}$ Twenty-nine states presently include property, payroll, and sales in their formulas. 1 P.H STATe \& Local TAX SERv. I 1046. While each factor is generally given equal weight, there are grounds for not doing so. See Wilkie, Interstate Apportionment of Business Income, 39 TAXEs 354, 356-57 (1961).

The Supreme Court has approved the "Massachusetts" formula. Alpha Portland Cement Co. v. Commonwealth, 268 U.S. 203, 215-16 (1925). Generally, the threefactor formula does not discriminate against the interstate taxpayer. Commonwealth v. Eastern Motor Express, Inc., 398 Pa. 279, 157 A.2d 79 (1959). However, the small plant can be penalized under such a formula. Hearings 133. Moreover, for some retailers, separate accounting is more valuable than apportionment because the three factors tend to distort their situation. Id. at 159-61.

50 The treatment to be afforded the sales factor has been the main obstacle to the adoption of a uniform formula. Hearings 94 .

51 Barber, supra note 24, at 1137-38 (1962). However, the property factor can involve the problem of capitalization of rents. Hearings 444. If rents are not capitalized, the corporation can avoid some of the state taxes by renting rather than buying property within the state. See, e.g., Budget Homes, Inc. v. State Tax Comm'n, 120 Utah 425, 235 P.2d 501 (1951).

Presently, fifteen states generally allocate payroll to the office location while twentythree states allocate the payroll to themselves if it was earned within the state. 1 P.H State \& Local TAx SERv. If 1048. However, unemployment insurance records supply much of the information required for payroll allocation.

Barnes, supra note 42, at 1278; Dane, supra note 37 , at 1204-05 (sale is an equal exchange, but author not opposed to inclusion of sales factor); Harriss, Interstate Apportionment of Business Income, 49 AM. Econ. REv. 398 (1959); Studenski, supra note 13, at 1131. Contra, Hartman, supra note 4, at 1101.

"3 Hartman, supra note 4, at 1101; Kust, supra note 2, at 16. This view is in accord with most authorities. 
from the formula, tax revenues would be concentrated in the predominantly industrial states with large property and payroll factors while the market states would realize little or no revenue under such a formula.

Postulating inclusion of the sales factor, it is unresolved as to what state the sale should be allocated for tax purposes-the state of the product's ultimate destination, the state of origin, or another state such as the state in which the order was accepted. Allocation of the sale to the state of origin again would deprive market states of revenue. 54

Once the taxpayer has calculated the fraction of income taxable by the state under a uniform formula, ${ }^{65}$ the income base must still be ascertained. Because of the numerous elements constituting an income base and the various definitional and regulatory incompatibilities conferred upon them by the states, uniform apportionment alone will not solve compliance problems. The adoption of a uniform definition of the income base seems to be equally necessary for a solution. ${ }^{56}$ Such a uniform definition would permit accounting

s\& In 1954 eight states had $56.82 \%$ of all manufacturing establishments and $62.73 \%$ of total payroll. Dep'T CoMmerce BuLL. MC-201 (1954). But see Barber, supra note 24, at 1138; Hearings 31 .

Yet, it is said that states premise taxation on the principle that the state has conferred on the taxpayer a benefit for which tax compensation is elicited; and in theory the sale is an equal exchange between buyer and seller. Danc, supra note 37 , at 1204-05.

The following authorities favor allocation of tbe sales factor to destination, which view would seem to represent the weight of opinion: Kust, supra note 2, at 17; Wilkie, supra note 49 , at 355. Contra Barber, supra note 24, at 1138; Britton, State Taxation of Extraterritorial Value: Allocation of Sales to Destination, 46 VA. L. REv. 1160 (1960); Harriss, supra note 52; Studenski, supra note 13, at 1131-32; Studenski \& Glasser, New Threat in State Business Taxation, 36 Harv. Bus. Rev., Nov.-Dec. 1958, p. 77.

As to the effect of the sales factor's allocation on compliance costs sce Kust, supra note 2, at 17; Lynn, The Uniform Division of Income for Tax Purposes Act Re.Examined, 46 VA. L. REv. 1257, 1267-68 (1960). Compare Hearings 94, 176, 446.

Of busincssmen surveyed, $75.4 \%$ favored the inclusion of the sales factor and $44.9 \%$ favored its allocation to destination. There was a great diversity of opinion among those favoring its allocation elsewhere. Controllers Institute of America Report to Council of State Governments, June 25, 1954, reprinted in Hearings at 479.

${ }^{\circ} \mathrm{As}$ to the question whether another state should be allowed to tax tbe corporate income when the state to which it is allocable does not, even though the corporation is subject to taxation by the non-taxing state, see, c.g., Lynn, supra note 54, at 1264; Uniform Division of Income for Tax Purposes Act of the National Committee on State and Local Taxation $\$ 14$, Controllers Institute of America, Feb. 27, 1959 (no re-allocation provided), reprinted in Hearings at 487; Uniform Division of Income for Tax Purposes Act of National Tax Association $\S 16$ (b) (2) (re-allocation), reprinted in Fearings at 503 .

${ }^{5}$ See Kust, supra note 2, at 13; Hearings 95, 257. If the federal base were adopted, a federal act would be required since individual action by states might be prevented 
methodology to be standardized and the income base to be determined uniformly for all state income tax returns, thereby lessening compliance costs. ${ }^{57}$

\section{Integration of Nexus aNd APPORTIONMENT}

The success of a uniform nexus statute is dependent upon the type and effect of the uniform formula enacted and the effect of the nexus statute on the state's administrative discretion. It is submitted, therefore, that the most effective remedy will be achieved when the combined impact of nexus, apportionment and discretion is considered.

If the sales factor is eliminated from a formula or allocated to a state other than the state of destination, the adoption of a permanent establishment nexus would be superfluous since the tax administrator probably would not endeavor to collect a tax under such an apportionment procedure unless there were large property or payroll factors within the state. However, if the sale is allocated to the state of destination and a permament establishment nexus adopted, the state could not tax a corporation earning large revenues within the state unless that firm also maintained a permanent establishment within the state. The ultimate tax consequence would be taxation of only those firms which have a permanent establishment and earn sufficient income to justify state collection costs, and the former requisite could be easily avoided by some corporations. Corporations whose modes of business require the utilization of a permanent establishment thus would be put at a competitive disadvantage.

If a quantitive nexus, measured by the dollar amount of business done within the state, is adopted, essential to an apportionment formula would be inclusion and allocation of the sales factor to the state of destination. Otherwise, such a nexus definition would be rendered nugatory. Since, as a practical matter, income is derived from sales and the use of a permanent establishment is not prerequisite to the realization of substantial income, a quantitive nexus would

by state constitutional prohibition of a graduated tax. See Opinion of the Justices, 99 N.H. 525, 113 A.2d 547 (1955). However, generally, this prohibition will not be present. See, e.g., Alaska S.S. Co. v. Mullaney, 180 F.2d 805 (9th Cir. 1950).

${ }^{57}$ In order to adapt a uniform federal plan to changing circumstances and to permit relief from its requirements when exigencies demand, it has been suggested that a federal agency be created or a presently existing one utilized, to administer the program. Hellerstein, State Taxation of Interstate Business: The Time Has Come for Uniformity, $16 \mathrm{~J}$. Taxation 246, 248 (1962). 
more likely correlate with income earned than where nexus is qualitatively defined. Such a procedure should in most cases produce competitive equality and tax revenue parity, and instances where corporate hardship would result could be alleviated by state administrative discretion. Furthermore, while the state could not as easily locate the taxpayer under a quantitative nexus as in the case of a qualitative nexus, a quantitative nexus should provide reasonable certainty of nexus and thereby facilitate voluntary tax compliance. 